meghatározottá vált a magyar mezőgazdaság és élelmiszeripar, de egyben az egész ország fejlődésének útja is. Az integráció a társadalom és a gazdaság egészére átformáló erövel hat. A kưlfooldi szaktudás, technika, tóke szabad áramlása, a nemzetközi gazdasági folyamatokba történő beilleszkedés, a küloónféle hátrányos megkúlönböztetések inegszúnése, a gazdaság modernizálódása. Mindez jótékony hatással lenne az ország gazdasági egyensúly: ra, a gazdaság növekedésére, a foglalkoztatási és regionális problémákra, tulajdonképpen az életszinvonal növekedésére. Természetesen e jótékony áramlások a magyar agrárgazdaság feltételeit is befolyásolják. Nem szabad azonban elfelejteni, ahhoz, hogy az ,integrálódottság" elönyeit, jótékony hatásait élvezhessük, hogy addig egyáltalán eljuthassunk, számos áldozatot, fájdalmas áldozatot kell hozni. És az áldozatok nem kis száma a magyar agrárgazdaságot fogja tovább gyengíteni. Ahhoz viszont, hogy az ágazat e számos korlátozás és „vérveszteség" mellett is jelentőségének megfelelő szerepet kapjon, a csatlakozás kủszöbére olyan állapotot kell teremteni, hogy a Közösségen belülre kerülve a nemzeti agrárpolitika dơntési szabadságának korlátozása idején erős, versenyképes, a követelményekre rugalmasan és sikeresen reagálni képes agrárágazat legyen.

Mivel a kötet az 1994. december végi helyzetet tủkrözi, viszont az európai integrációs folyamat konkrét viszonyai, szabályai rendkívül gyorsan változnak, az e könyvben foglaltak egyfajta "kulcsot" adhatnak a Közös Agrárpolitika és az ahhoz kapcsolódó újabb, olykor rövid idón belül is módosuló új jelenségek megértéséhez, rendszerbe illesztéséhez.

Csató Péter

\title{
ÁTALAKULÓ MAGYAR MEZŐGAZDASÁG
}

\author{
INFO-Társadalomtudomány 36.
}

Kissé rendhagyó módon most nem egy megjelent könyv, hanem egy folyóirat Info-Társadalomtudomány 36. száma ismertetésére kerül sor. E szám fontosságát tartalma indokolja. Az átalakuló mezõgazdaságról (1990-től napjainkig) kevés olyan tudományos mú ad hiteles információt, mint e folyoirat, amely igen széles vertikumban foglalkozik a mezőgazdaság jelenével, jövơbeni kilátásaival.

A változásokat, változtatási törekvéseket nagy mértékben meghatározó olyan okok is, amelyek a kỏzel, illetve a távolabbi múltban gyỏkereznek. Erre hívja fel a figyelmet Sipos Aladár: A magyar mezỏgazdaság öröksége és jelene c. tanulmányában. A szerzó egészen 1945-tól figyelemmel kíséri és az olvasó elé tárja a téma szempontjából fontosnak tartott fejlödési irányokat. Konkrét számadatok szólnak az adott idószak termelési színvonaláról, a gépesítettség arányáról, a kis- és nagygazdaságok eredményes együttmúködéséról, továbbá a 80-as évek elejére az állami támogatást elveszítő mezőgazdaság sorsáról. A 90-es évek változásait kơvetően olyan számadatok is rendelkezésre állnak, amelyek azt mutatják, hogy a mezógazdaság teljesítménycsökkenése csaknem azonos az 1938-39. valamint az 1946-47. évi termelés visszaeséssel. A problémák mellett olyan teendőkröl is szó esik, mint pl. a hazai piac védelme, a fôként Európai Unióból származó és magas exporttámogatást élvezố termékekkel szemben, valamint az állami szerepvállalás, a támogatási 
rendszer újragondolása, a politikában és pénzügypolitikában való megfelelö elhelyèzése.

A tulajdonviszonyok, valamint a termelési struktúra változásáról csaknem minden szerző szól, azonban Varga Gyula által írt cikk kifejezetten e problémakörből meríti témáját. A szerző szerint az átalakítás igen nagy károkat okozott a mezógazdaságban, $s$ ennek szerves részeként negatívan érintette az abból élök életviszonyait is. A cikk írójának jó néhány megállapításával nem tudok egyetérteni, mint pl. ,az a sehol sem bizonyított állitás volt, amely szerint az államnál nem lehet rosszabb tulajdonos" (23, o.). E tény bizonyítására - véleményem szerint - az elmúlt közel negyven év igen jó adalékul szolgált. Igaznak tekinthetó a szerzó azon megállapitása, mely szerint a változtatások felülről jövők és ideológiai tôltetủek voltak. Az a megállapitás viszont ismét vitatható, hogy ez alapjában véve csak kudarccal járt. A jelenleg eredményesen müködő nemzetgazdaságok alapja a magántulajdon. Azt a gazdasági formációt ez ideig nem találták ki, ahol a tulajdonosok szerepét az állam veszi át, illetve kitalálták csak annak bevezetése teljes kudarccal járt.

Az államnak - ha nem is tulajdonosként - igen fontos szerepet kellene betöltenie (fóként a jogi szabályozás útján) a mezógazdaság fejlesztésében, az egyensúlyi helyzetek megerósítését célzó folyamatokban. Ezt, illetve ennek hiányát emeli ki Halmai Péter: Agrárpiaci szabályozás és piacgazdasági átmenet c. tanulmányában. A cikket olvasva úgy tünik, hogy az állam még e feladata ellátása során sem állt a helyzet magaslatán, a szerzőt idézve a „rendszer eddigi múködésének mérlege kiábrándító". E megállapitást igen sok ténnyel igyekszik alátámasztani, pl. a minimálárak képtelenek piacszabályozó funkciót betölteni, ugyanis azokat irreálisan alacsony mértékben állapították meg. Hasonlóképpen tisztázatlanok a piacpolitikai célok, hiányosak, bizonytalanok a piaci információk. A rendtartási kassza nem funkciojának megfelelően múködik, hiszen egyes támogatások, mint pl. a gázolaj fogyasztási adojának visszatéritése, természeti káresemények következményeinek elhárítása, a piacszabályozási feladatoktól igen távol állnak. A szerzó állitásai szerint a rendtartási törvény módositásai sem hozták meg a várt eredményt, pontosabban „a piac épitése helyett annak múködését korlátozó szabályokra került a hangsúly". Úgy túnik, hogy a rendtartás területei közül az egyedül müködóképes rész az exporttámogatási rendszer. Fontos megállapítása a cikknek, hogy egyes beavatkozások nincsenek szinkronban vagy éppen kapcsolatban - az azok alapjául szolgáló eseményekkel, melynek fö oka a torz, vagy hiányzó információ. A beavatkozások gyakran nemcsak hogy információk nélkül, de az egyes érdekeltek nyomására, illetve azok érdekérvényesítő képességétől függenek. A döntéshozók adott esetben - azt sem képesek megítélni, hogy felesleg vagy hiány van-e a piacon.

Hiányzik a csoportos értékesítés és a koordináció. Ezzel a témával foglalkozik behatóbban Szabó Márton: Intézmények, szervezetek, integráció c. cikkében. A problémát elsősorban a kereskedelem aspektusából közelíti meg. A szerző rámutat arra, hogy a 90-es években a mezőgazdasági, kereskedelmi szervezetrendszer több szereplöje megszünt létezni, illetve a régi piaci szereplő́k a változó körülményeknek megfeleló új szerepet töltenek be. A régi szereplők mellett új piaci intézmények jöttek létre (pl. árutőzsde), melyek hatást gyakoroltak a mezőgazdasági kereskedelem dinamikus fejlódésére.

Mezógazdaságunk fejlődése elválaszthatatlanul összefügg a termékek külpiacon történỏ értékesitési lehetőségeivel is. Ezt a problémakört járja körül Kiss Judit: Agrárkülgazdaságunk változásai c. tanulmányában. A szerző sorra veszi azokat a tényezóket, amelyek a közelmúltban mezőgazdasági külkapcsolatainkra negatív 
hatást gyakoroltak. Ilyeneknek tekinthetök pl. a külpiacok megváltozott fogadókészsége (a recesszió következtében létrejött keresletcsökkenés), a fejlett országok protekcionista intézkedései, a hazai termelés minóségi és mennyiségi romlása, továbbá új EU-tagok (korábbi piacot jelentő országok) csatlakozása. Fontos megállapítása a szerzónek a volt KGST-tagállamok külpiaci részesedésére vonatkozó kijelentés. Ez azt tartalmazza, hogy a közhiedelemmel ellentétben „ezen országcsoportok súlya mindvégig $30 \%$ körül ingadozott, majd a 90-es évek közepére 45\%-ra emelkedett". Bóvebben olvashatunk a tanulmányban, olyan aktuális kérdésról is, mint az EU csatlakozás problémája. A kérdés azért is fajsúlyos, mert az EU költségvetés tỏbb mint $50 \%$-át fordítják agrártámogatásra. A szerző felveti azt a kérdést, hogy vajon Európai Uniónak érdekében áll-e a hazai mezb́gazdaságot saját forrásaiból fejleszteni, amikor a mezőgazdaság az. Unión belül is folyamatosan gondokat okozó ágazatot képvisel. Esélyeink mindenképpen akkor válhatnak kedvezöbbé, ha mezőgazdaságunk a csatlakozási tárgyalások kezdetére nagy mértékben modernizált, versenyképes termékekkel kerül az EU vizsgáló szemei elé.

Olyan fontos témával, mint a mezógazdasági átalakulás társadalmi hatásaival fog lalkozik Kovách Imre azonos c. tanulmánya. A szerzỏ a 90-es évek változásait a jobbágyfelszabadításhoz az 1945-ōs fỏldosztáshoz, vagy éppen a 60-as évek kollektivizálásához hasonlítja. Külön foglalkozik a mezỏgazdasági magánszektorral amely a szocialista idókben a családi termeléssel volt azonos - továbbá a családi gazdaságok fejlődésével 1992-ben és 1992-95 közőtt. A kutatások kiindulási alapjául az ún. farmergazdaságok szolgáltak, amelyek az imént jelzett idószakban erós differenciálódáson mentek keresztül. A tanulmányból kitúnik, hogy Magyarországon két meghatározó típusú családi gazdálkodás van kialakulóban: az egyik fỏként önellátásra szakosodik, jellemzóje a szakértelem, a tóke, a modernizáció hiánya, míg a másik esetben a specializációnak a magas szakképzettségnek és nagyfokú termelékenységnek lehetünk tanúi.

A folyóirat tanulmányaiból néhány és elkerülhetetlenül önkényesen kiragadott pillanatkép talán alkalmas arra, hogy felkeltse az érdeklódését azoknak, akik valamilyen módon érdeklödnek a magyar mezögazdaság jelene és jövöje iránt. Az adatokban és a tudományos megközelítések sokszínüségében gazdag cikkek tanulságos olvasmányul szolgálhatnak a hozzáértők számára.

Finta István 